УДК $82-93$

\title{
Філатова Оксана,
}

доктор філологічних наук, професор, завідувач кафедри української мови і літератури

Миколаївський національний університет імені В. О. Сухомлинського

\section{РОМАН ВИХОВАННЯ О. КОПИЛЕНКА: СВОСРІДНІСТЬ ЖАНРОВОЇ МОДЕЛІ}

У статті простежуємо розвиток в украӥнській літературі початку XX століття роману виховання, з'ясовуємо характеристики жанрової модифікації. На матеріалі дилогії О. Копиленка “Дуже добре” $i$ “Десятикласники” аналізуємо наскрізні проблемно-тематичні компоненти та стильові домінанти, щь визначають зміст ідеологічного проекту виховання.

Ключові слова: роман виховання, дилогія, жанрова модифікація, сюжет, хронотоп, герой, соиреалізм.

Upbringing novel by $O$. Kopylenko: the peculiarities of the genre model.

The article investigates the development of upbringing novel in the Ukrainian literature of the beginning of the 20th century. It clarifies the characteristics of the genre modifications. On the material of the dilogy written by O. Kopylenko "Very Good" and "Tenth-graders", the research analyzes problem-thematic components and style dominants, which determine the content of the ideological project of education. realism.

Keywords: novel of upbringing, diology, genre modification, plot, chronotop, hero, socialist

Роман виховання - один із доволі поширених жанрів як в українській, так і у світовій літературі. Серед конститутивних ознак цього «багатостильового, різномовного, багатоголосого явищу $\gg$ [Бахтин 1975 : 75] 3 виразною 
композиційно-стильовою єдністю, літературознавці виокремлюють певний тип героя, характерний сюжет і проблематику, пов’язані з соціальним і моральнодуховним формуванням героя, набуття ним інтелектуального, емоційного та практичного досвіду; мотив ініціації, дидактизм фіналу тощо. Роман виховання (або виховний роман) займав одне 3 центральних місць в системі класової семантики соціалістичного реалізму, «демонструючи радянському читачеві, яким важливим є виховання нового типу особистості в умовах будівництва нового життя» [Болдырева]. Яскравим зразком виховного роману, наснаженого «соціально-етичною, соціально-педагогічною проблематикою», у 30-ті роки XX століття стали романи I. Микитенка «Ранок», Л. Смілянського «Зустрічі», автобіографічна трилогія Ю. Смолича «Дитинство», «Наші тайни» «Вісімнадцятилітні», повість «Школа над морем» О. Донченка, що репрезентували тему утвердження «нової соиіалістичної моралі... молоді» [Смульсон 1939 : 97], «масового виховання ци перевиховання людей”, “формування юної душі в бурях і трудах віку» [Новиченко 1976 : 24, 41].

Так, в епічних полотнах Івана Микитенка і Леоніда Смілянського жанрові ознаки вихованого роману простежуються на рівні сюжетики, оповіді (оповідач, суголосний з інтенціями автора), конфлікту, розвитку та формування характеру головного героя. В обох творах сфера авторської обсервації фокусується на процес перебудови колишніх сиріт і безпритульних, які під впливом колективу вихователів стають чесними й відданими будівниками соціалізму. Якщо в першій книзі роману «Ранок» (твір незавершений, написана тільки одна частина.- О. Ф.) зображена ціла галерея образів правопорушників, що стали на злочинний шлях, але завдячуючи роботі вихователів і чекістів, трудовій комуні та колективній праці поступово духовно «перероджуються», пізнають силу праці, то в романі «Зустрічі» процес перевиховання проходить молодий червоноармієць зі складним характером, у минулому безпритульний вуличний хлопчисько Семен Барабаш. Такий вибір героя, ймовірно, давав змогу письменникам наочно зобразити моральне одужання «колишніх блатних», їхній шлях від босяцьких уявлень про свободу особи до розуміння 
свободи як «усвідомленої необхідності жити за законами колективу, суспільства» [Острик 1964 : 58]. У період пошуку близьких за духом людей, боротьби зі складнощами світу (часом із власною бунтівною вдачею) ці молоді люди врешті-решт духовно перебудовуються і морально мужніють. Зокрема Семен Барабаш в атмосфері військової дисципліни та вимог армійських командирів не лише набуває досвіду, дорослішає, але й знаходить себе і свою місію у цьому світі, репрезентовану автором у традиційному для радянського виховного роману форматі: «немає вже тих сумнівів, щзо туманили колись його свідомість. Немає важких турбот про своє майбутнє, а тільки думки про ту роль, до якої внутрішньо підготував він себе иілком... без якої він не мислить $i$ самого себе. “Поки живуть вороги - щзастя умовне”, - це він говорить собі тепер. I в готуванні себе до майбутньої боротьби на кордонах незмірених просторів батьківщини знаходить місие собі, своїй бунтівній невгамовній вдачі...» [Смілянський 1936 : 233].

Виразні жанрові характеристики роману виховання має дилогія «Дуже добре» (1936 р.) і «Десятикласники» (1938 р.) Олександра Копиленка. Створений на замовлення адептів нового утопічного дискурсу твір українського письменника став корелятом епохи тридцятих років, культовим зразком офіційної масової культури, на яку покладалася суспільно важлива місія репрезентанта панівної ідеології, дієвого засобу політичної пропаганди. Власне, так само, як «Школа над морем» Олеся Донченка і «Дев”ятий “А”» Григорія Мединського - повісті із заздалегідь визначеною ритуалізованою схемою та обов’язково оптимістичним фіналом).

Прикметно, що написані за вказівкою влади твори «шкільної» тематики (за невеликим винятком) не заслужили пошани ні в чиновників від літератури, ні в критиків. Не маючи можливості відверто сказати про замовний i пропагандистський характер текстів, «принципові» дослідники того часу звертали увагу читачів на анекдотичну схожість повісті Мединського і дилогії Копиленка [Ивич 1940; Смульсон 1939], критикували фальший пафос, «майже одночасні та водночас помилкові відкриття», зроблені авторами в дилогії 
«Дуже добре» $\mathrm{i}$ «Десятикласники», у повістях «Школа над морем» i «Дев’ятий “А”». «У иих книжках серйозні питання ставляться несерйозно, немає справжніх конфліктів, все позбавлено різкості, все плавно $i$ штучно, як у підводному иарстві опери “Садко”, - вважав Ю. Нагибін. - Після їхнього прочитання молодий читач як і раніше залишиться наодинці з самим собою, нічому не навчивщись, ні в чому не побачивщи поради або втіхи» [Нагибин $1940: 7]$.

У дилогії О. Копиленко детально й різноаспектно показав життя школи як учнів, так і вчителів - другої половини $30-\mathrm{x}$ років XX століття в нерозривному зв'язку з життям усієї країни, відтворив чимало прикметних подробиць тогочасного ідеологічно-зашореного життя (приховане шкідництва у школі, боротьба чесних педагогів з авторитарним директором-розтратником та вчителем-білогвардійцем, протистояння міщанській ідеології, «перековування» мудрими наставниками-вчителями несвідомих батьків і под.). Паралельно до основної сюжетної лінії про обставини життя й навчання учнів, їх дозвілля, стосунки між учнями та вчителями у романах «Дуже добре» i «Десятикласники» розгортається ще одна важлива сюжетна лінія - сімейних взаємин (ставлення до дітей у сім’ї, мікроклімат у родині, конфлікти i розлучення батьків, взаємини між учителями, у тому числі інтимного плану), що впливають на формування характеру і світоглядних позицій школярів.

Стандартизовані трафарети соцреалістичної естетики визначають у романах проблематику, конфлікт і ключові соціальні ролі персонажів. Якщо в романі «Дуже добре» авторські реляції зорієнтовані на проблемі формування особистості школяра-підлітка в умовах колективістських взаємовідносин, то в «Десятикласниках» увага сфокусована на гартуванні характеру колишніх семикласників, на міжособистісних стосунках юнаків і дівчат, першому коханні молодих людей як важливої події цілеспрямованого процесу соціалізаціїініціації. Відтак, фабульно-сюжетний час обох творів вбирає події кількох років - від початку особистісного формування та виховання дітей перехідного 
віку до набуття досвіду, дорослішання, пізнання сили кохання i дружби, визначення десятикласниками своєї місії в житті.

В індивідуально-авторській інтерпретації позитивні персонажі роману дилогії позначені неабиякою енергійністю, дієвістю, наполегливістю, вони постійно працюють (i не тільки на уроках) та допомагають іншим. Школярі виконують громадські доручення: стають піонервожатими на громадських засадах і допомагають учителям виховувати учнів молодших класів, опікуються тваринами i птахами в зоологічному кабінеті школи, організовують аеромодельний i драматичний гуртки, організовують виставки. 3 молодечим завзяттям та ентузіазмом прагнуть (аналогічно до намагань позитивних героїв «дорослої» літератури) самоутвердження, романтики подвигу, рішучо долають будь-які перешкоди на шляху до омріяної мети. Тому й чинять організований опір колишньому бандиту вчителю географії Чернусі та пишуть листа в ЦК партії і народному комісару освіти, в якому розповідають про шкідницьку діяльність завідувача Корокута, що привласнив шкільні гроші. «Майбутні творці майбутньої історії», «нового світу» не лише соціально активні у громадському житті, наполегливі в навчанні і спорті, але й справжні патріоти й захисники країни, здатні до героїчних вчинків. Героїчного характеру в дилогії Копиленка набуває як боротьба 3 індивідуальними вадами (егоїзмом, індивідуалізмом, міщанськими звичками, ідейною короткозорістю, недисциплінованістю i т.п.), так і бажання випробувати себе, відчути справжніми звитяжцями, лицарями-бійцями, вистежуючи зокрема підозрілих осіб або затримуючи шпигуна, що був особливо небезпечний, коли діяв у згоді iз внутрішнім ворогом. Цілком очевидно, що хвиля шпигуноманії, що заполонила простір суспільно-політичної комунікації 1930-х років, знайшла відображення у художній площині роману «Десятикласники». Неодноразово в тексті автор акцентує на потребі формувати не просто пильність, а гіпертрофовану пильність, адже «іноземні ипигуни, порушники кордонів та вороги... пролазять $i$ шкодять усюди». В готових, клішованих формах прописує для героїв обов’язкові сценарії поведінки («повинна бути 
мобілізована кожна родина, кожен громадянин» [Копиленко 1969 : 368]; «треба уміти розпізнавати ворога, треба бути пильним» [Копиленко 1969 : 369]), впроваджуючи таким чином у свідомість читача пропагандистську версію перманентної боротьби, доводячи ії необхідність.

Письменник уважно прослідковує процес розвитку характеру героя. Неважливо, чи це стосується переходу від дитячої наївності, недосвідченості до морально змужніння та ідейної зрілості Аркадія Трояна, чи соціального становлення особистості Марка Бобиря, якому через помилки й життєві випробування довелося пройти шлях від злочину до духовного відродження, апогеєм якого стає вступ до комсомолу. В обох випадках йдеться про боротьбу за нову самоідентичность, зокрема подолання в позитивному героєві ознак стихійності та формування високої свідомості. Логіка еволюції Аркадія і Марка детермінує необхідність змінити погляди, власну поведінку, стати кращим перед товаришами, перед дорослими, перед школою, піонерською організацією, комсомолом, партією, перед соціалістичною батьківщиною, що «дала радянським дітям щасливе дитинство».

Так, скажімо, якщо спочатку вся система морально-політичних асоціацій Трояна будується на традиційних явленнях (у риториці зрілого сталінізму наївних і несвідомих. - О. Ф.) про боротьбу з ворогом (юнак ненавидить ворога, «має сильні м’язи, здорове тіло, міцний, несхибний дух»), то обман шпигуна Івана Медового, який входить у довіру до Аркадія та проникає в сім'ю конструктора Галайди й ледве не викрадає секретні матеріали, надає їм іншого формату. Гіперболізовані символи небезпеки, очікування загрози, що набувають у житті десятикласника ознак перманентності, а згодом усвідомлення власної провини (у тоталітарній системі координат - злочину) позбавляють його від ідеалізму і мрійливості, загартовують, роблять старшим.

Динаміка внутрішнього розвитку характеру Марка Бобиря, мотиваційна сила його вчинків вже традиційно для ідеологічно інспірованих текстів розкривається в зіткненнях і випробуваннях, у яких герой прагне опанувати себе, рухаючись від індивідуалізму як ознаки стихійності до колективізму - 
вищої форми свідомості. У підлітковому віці учень неабияких здібностей Марко зв'язується 3 поганою компанією, починає читати заборонені книжки (дореволюційні), грати в карти, пити горілку, зрештою, стає на шлях злочину викрадає державні гроші 3 портфеля своєї мачухи. Під впливом радянської дійсності, комсомольського активу в юнака змінююється поведінка, розвивається “висока свідомість”, гартується характер. Герой приходить до необхідності підпорядкувати індивідуальну ініціативу i власні переконання думці колективу. Сцена вступу Бобиря до комсомолу, його виступ перед однокласниками є ритуалом із глибоко символічним змістом, що підтверджує результат “перевиховання” зовнішньою авторитетною інстанцією: «...не криючись Марко розповів усе - про відрив від коллективу, про свою замкненість, коли треба було дружит из товаришами... Друзу допомогли перебороти сумніви. Але хотілося б довести й роботоюб й ділом, щзо він маж право увійти в щзасливу комсомольську сім'ю. Шукав геройчного вчинку, чекав нагоди виявити сбе, а такої нагоди не було. Заздрив товаришам і мучився. Так $i$ не зробив нічого великого, Але наше життя велике - i нагода щуе буде» [Копиленко 1969 : 388].

Авторська увага у другій частині роману «Десятикласники» більше сфокусована на внутрішньому світі героїв, на їхніх переживаннях, пов’язаних із життєвими радощами й надіями, труднощами й розчаруваннями, представлених автором у антуражі життя радянської людини передвоєнного періоду. Треба віддати належне Копиленкові, який, попри стандартизовані трафарети щодо ідеологічно вмотивованої образно-смислової структури твору, локус авторської уваги зміщує в бік індивідуально-особистісного, а не соціально значимого. Точніше, показуючи формування героїв як певних соціальних типів, як постатей соціальної ідеології, автор дилогії разом 3 тим виділяє незмінні психологічні константи, пов’язані з віковими особливостями.

Відтворюючи властиву молоді того часу ідейно-емоційну піднесеність, щиру схвильовану атмосферу навчання, письменник зосереджується на іманентних потенціях вчорашніх підлітків, що стали дорослими й серйозно 
задумуються над своїми вчинками, над суперечностями i конфліктами, які, до речі, завжди завершуються примиренням (випраленням негативного).

Щирими й приникливими в романі $є$ картини, в яких розкриваються інтимні взаємини героїв: народження кохання Кіри Коваль і Аркадія Трояна, взаємної симпатії Руфи Гольдман і Вови Поради, Тамари Незабудь і Віктора Мартинова. Народжене 3 дружби перше кохання десятикласників, позбавлене протиріч, гармонійне, одночасно й романтичне, i вповні приземлене. Показуючи дружбу десятикласників, Копиленкові вдається відійти від розуміння дружньої вимогливості та принциповості як морального покарання особи за найменшу дрібницю, характерні у стосунках підлітків. Згадаймо, як жорстко розправився семикласник Вова Порада з улюбленою лялькою Кіри, розірваши іграшку на клапті, звинуватиши подругу у «страшному злочині»: «Піонерка, голова загону бавиться з лялькою! Цим займаються тільки буржуазні елементи! За це ж галстук з тебе треба негайно зняти! Я поставлю питання на раді загону! Ми тебе проробимо на зборах» [Копиленко 1969 : 175]. Чи Аркадій Троян на контрольній 3 математики повідомив учителеві й класу, що голова піонерзагону «Кіра Коваль списала контрольні завдання, обманула вчителя і всіх нас».

У другій частині дилогії зросла питома вага «розуміння» друга, прагнення вникнути в сутність його проблем, підтримати і словом, і справою. Разом із тим автор представляє радянський варіант дружби i любові між юними громадянами нової генерації, сформований на основі утвердження чесності та «життя в ім'я людей». Визначальною рисою характеру надмірно ідеалізованих героїв Копиленка $є$ самопожертва на користь інших, колективу. На підтвердження цього можна навести фрагмент роману, коли головна героїня роману запальна Кіра Коваль обурюється, коли хтось насміхається над однокласниками (часом ïi реакція має яскраво виражений штучний характер), стає на захист сироти Тамари Незабудь від опікунів Пещер - колишнього білого поручика і власниці готелю. Дівчина підтримує свого товариша Аркадія Трояна у складній ситуації, увесь драматизм якої полягає у виключенні 3 
піонерської організації, а той у свою чергу різко картає старосту класу Вову Пораду за негідний вчинок - підказки на уроці: «Комсомолещь, який допомагає своєму товаришу... робитись ледарем, не вчитись, списувати... Чого вартий такий комсомолецьь? - наступав Аркадій.

- А ти за мене не турбуйся, - виходячи з класу, недбало сказала Маруся.

- Я повинен про всіх турбуватись, і ти теж...» [Копиленко 1969: 300-301].

Палко обстоюючи думку про чистоту дружби («дружба $\epsilon$ святе, велике почуття», «комсомолецьь має бути абсолютно чесним $i$ чистим»), сенс справжньої товариської допомоги принциповий Аркадій Троян вбачає в тому, «щуоб не прощзати другові ні його хиб, ні помилок» [Копиленко 1969 : 337]. Тому для безкомпромісного лідера десятикласників Сашко Мостовий не просто хуліган, а й особистий недруг, як власне й однокласники - егоїст і позер Яша Баркін та модниця Маруся Рожко.

Процес ініціації з оптимістичним финалом, який проходять Копиленкові герої, відбувається за підтримки однокласників і під впливом старших товаришів-наставників, що репрезентують нормативну систему координат: завпеда-комуніста Кужеля, вчительки історії Райко (в «перевихованні» Марка вона відіграла найпомітнішу роль), конструктора Галайди, полковника Поради, який впливав на Аркадія «непомітно, може, навіть мимохіть, але впливав глибоко». Іншими словами, молоді люди піддаються ряду випробувань і після успішного їх подолання стають повноцінним «членами родового співтовариства» (К. Кларк). Свідомо прагнучи досягнення своєї мети, і Аркадій Троян, і Марко Бобир, досягають соціальної та колективної інтеграції, а не індивідуальної ідентифікації власне самих себе.

Роман-виховання періоду становлення канону соцреалізму - один із найяскравіших художніх документів, крізь який прочитується політика радянської влади. Чи не всі колізї дилогії О. Копиленка «Дуже добре» i «Десятикласники» мотивовані в першу чергу реальним життям тогочасного суспільства, активно декларовані в лозунгах і плакатах, промовах і підручниках адептів нового утопічного дискурсу, які безпомилково орієнтувалися у зміні 
ідеологічних векторів. Роль автора-творця в образно-смисловій структурі таких текстів зводиться до банальної функції ілюстратора-оформлювача.

\section{БІБЛІОГРАФІЯ}

Бахтин 1975 - Бахтин М. М. Вопросы литературы и эстетики. - Москва : Художественная литература, 1975. - 504 с.

Болдырева - Болдырева Е. М. От «Педагогической поэмы» к «педагогической идиллии» / Е. М. Болдырева // Електронний ресурс. - Режим доступу : http://vestnik.yspu.org/releases/novye_Issledovaniy/14_9/

Ивич 1940 - Ивич А. Три повести о школе / А. Ивич // Литературное обозрение. - 1940. - № 9. - С. 19-25.

Копиленко 1969 - Копиленко О. Дуже добре. Десятикласники. Романи / Олександр Копиленко. - Харків : Харківська книжкова фабрика ім. Фрунзе, 1969. - $402 \mathrm{c}$.

Нагибин 1940 - Нагибин Ю. Школьная тема : “Школа над морем” / Ю. Нагибин // Детская литература. - 1940. - № 9. - С. 6-9.

Новиченко Л. М. 1976 - Український радянський роман : стислий нарис історії жанру / Л. М. Новиченко. - Київ : Наукова думка, 1976. - 130 с.

Острик 1964 - Острик М. Леонід Смілянський. Критично-біографічний нарис / Михайло Острик. - Київ : Рад. письм., 1964. - 185 с.

Смілянський 1936 - Смілянський Л. Зустрічі: роман / Л. Смілянський. Київ : Молодий більшовик, 1936. - 236 с.

Смульсон 1939 - Смульсон Л. Образи і схеми: про успіхи і хиби роману “Десятикласники” / Л. Смульсон // Літературна критика. - 1939. - № 4. C. $98-109$.

Філатова 2017 - Філатова О. Автор і текст у системі соцреалізму : монографія / Оксана Філатова - Миколаїв : Іліон, 2017. - 244 с. 